\title{
Nowoczesne technologie w kardiologii interwencyjnej w świetle najnowszych badań
}

\author{
New technologies in interventional cardiology in the light of the latest research
}

\author{
Michał Plewka \\ Katedra i Klinika Kardiologii Uniwersytetu Medycznego w Łodzi
}

Od 29 października do 2 listopada 2016 roku, w Waszyngtonie, odbył się doroczny, już 28., kongres kardiologii inwazyjnej TCT. Jak zawsze na sesjach hot-line zaprezentowano wiele ważnych badań, opublikowanych równocześnie we wiodących czasopismach kardiologicznych.

Jednymi z najbardziej komentowanych były rozczarowujące wyniki trwającej 3 lata obserwacji badania bioabsorbowalnych rusztowań naczyniowych (BVS, bioresorbable vascular scaffold) generacji GT1 - ABSORB II [1] u pacjentów z chorobą wieńcową, którym zaimplementowano uwalniający ewerlimus BVS Absorb ${ }^{\circledR}$ lub metalowy stent uwalniający ewerolimus (EES, everolimus eluting-stant) Xience $^{\circledR}$. W randomizowanym (2:1) badaniu wzięło udział 501 pacjentów; stent Absorb $^{\circledR}$ zastosowano u 335 osób, a stent Xience ${ }^{\circledR}-$ u 166. Idea stosowania BVS zakładała szczególne korzyści, zwłaszcza w obserwacji odległej, w której - po całkowitej resorpcji rusztowania - miały zostać zniwelowane późne działania niepożądane, takie jak przedłużone gojenie się, zapalenie czy też nawrót blaszki miażdżycowej lub późna zakrzepica w stencie.

Okazało się, że BVS Absorb ${ }^{\circledR}$ GT1 w porównaniu ze stentem Xience ${ }^{\circledR}$ nie poprawiał aktywności wazomotorycznej stentowanego naczynia, co było jednym z podnoszonych mechanizmów potencjalnej przewagi nad klasycznymi stentami (Absorb ${ }^{\circledR}$ 0,047 mm [odchylenie standardowe \{SD, standard deviation 0,109$]$ v. Xience ${ }^{\circledR} 0,056 \mathrm{~mm}$ [SD 0,117]; p superiority $=0,49)$. Późna utrata światła w stencie była większa w przypadku wykorzystania BVS niż EES $(0,37 \mathrm{~mm}[0,45]$ v. 0,25 mm [0,25]; p non-inferiority $=0,78)$, co potwierdzono również w danych z badania przeprowadzonego metodą ultrasonografii wewnątrznaczyniowej (IVUS, intravascular ultrasound) $\left(4,32 \mathrm{~mm}^{2}\right.$ [SD 1,48] v. $5,38 \mathrm{~mm}^{2}$ [1,51]; $p<0,0001)$.
Nie stwierdzono istotnej statystycznie różnicy w zakresie drugorzędowego klinicznego punktu końcowego (Seattle Angina Questionnaire score), jak również w wynikach próby wysiłkowej. Wykazano natomiast istotnie gorsze wyniki dotyczące złożonego punktu końcowego (zgon, zawał serca, rewaskularyzacja) w odniesieniu do BVS (10\% v. 5\%, współczynnik ryzyka [HR, hazard ratio] 2,17 [95-proc. przedział ufności \{Cl, confidence interval\} 1,01-4,70]; test log-rank $p=0,0425)$, na co składało się przede wszystkim wielokrotnie wyższe ryzyko zawału serca po implantacji BVS niż po implantacji klasycznego EES ( $6 \%$ v. $1 \% ; p=0,0108$ ). Zwrócono również uwagę na wyższe ryzyko późnej zakrzepicy w BVS, mimo przedłużonej podwójnej terapii przeciwpłytkowej (DAPT, dual anti-platelet therapy). Podsumowaniem wyników niech będzie komentarz głównego autora publikacji - Prof. Patricka Serruysa, który stwierdził, że nie takich wyników oczekiwano. Broniący idei rusztowań bioabsorbowalnych podkreślali konieczność właściwej techniki zabiegu (tzw. PSP), obejmującej przygotowanie naczynia, dobór średnicy rusztowania i postdylatację, optymalnie pod kontrolą IVUS/optycznej tomografii koherencyjnej (OCT, optical coherence tomography). Nadzieje wiąże się także z zastosowaniem nowszych generacji BVS.

Interesującą nowością mogą być tak zwane stenty wypełnione lekiem (DFS, drug-filled stents), pozbawione niektórych ograniczeń związanych z obecnym na powierzchni polimerem. Z technicznego punktu widzenia DFS składają się z trzech warstw tworzących sieć stentu. Wewnętrzna warstwa jest zbudowana z tantalu, co podwyższa widoczność w promieniach RTG. Z kolei zewnętrzna warstwa kobaltowo-chromowa - odpowiada za siłę radialną stentu. Istotą DFS jest wewnętrzny kanał w strukturze stentu na całej długości, pokryty od wewnątrz lekiem (sirolimusem

Adres do korespondencji: dr hab. n. med., prof. UM Michał Plewka, Katedra i Klinika Kardiologii Uniwersytetu Medycznego w Łodzi, ul. Kniaziewicza 1/5, 91-485 Łódź, tel. 4265399 09, e-mail: plewka@ptkardio.pl 
w przypadku obecnie badanego stentu). Lek wydostaje się poprzez wykonane laserowo otwory od strony ściany naczyniowej stentu, o średnicy około $20 \mu \mathrm{m}$, w ilości około 1800 w typowym 18-milimetrowym stencie. Pozwala to na równomierne przechodzenie leku bezpośrednio do ściany naczynia.

Przedstawiono pierwsze wyniki (first in human) badania RevElution [2], do którego włączono 101 pacjentów. Obserwacja trwała 9 i 24 miesiące. U pierwszych 50 pacjentów włączonych do analizy pierwszorzędowego punktu końcowego utrata światła w stencie DFS wynosiła 0,26 mm, co oznaczało spełnienie kryteriów non-inferiority w porównaniu z wcześniejszymi danymi dotyczącymi DES (Resolute ${ }^{\circledR}$; $p<0,001)$. Dodatkowo w przypadku DFS stwierdzono niski odsetek zdarzeń niepożądanych (TLF, target lesion failure), definiowanych jako zgon, zawał serca i rewaskularyzacja związana z docelowym zwężeniem (2,1\%), oraz brak zakrzepicy w stencie (0\%) w okresie 9 miesięcy. W badaniu metodą OCT wykazano szybkie gojenie w miejscu implantacji z pokryciem stentu przez śródbłonek w 91\% po miesiącu, w ponad $95 \%$ po 3 miesiącach oraz w $99 \%$ po 9 miesiącach.

Równocześnie przedstawiono wyniki badania BIO-RESORT-TWENTE III [3], służącego porównaniu dwóch stentów z biodegradowalnym polimerem (uwalniającego sirolimus Orsiro ${ }^{\circledR}$ i uwalniającego ewerolimus Synergy ${ }^{\circledR}$ ) oraz stentu z klasycznym polimerem (uwalniającego zotarolimus Resolute Integrity ${ }^{\circledR}$ ).

Badanie przeprowadzono w czterech ośrodkach w Holandii; zrekrutowano kolejnych 3514 pacjentów (70\% z ostrym zespołem wieńcowym). Po randomizacji 1:1:1 chorych przydzielano do trzech grup: 1) w której implantowano stent uwalniający ewerolimus, 2) w której implantowano stent uwalniający sirolimus, 3) w której implantowano stent uwalniający zotarolimus. W badaniu potwierdzono hipotezę o równoważności trzech badanych stentów ( $\mathrm{p}$ dla non-inferiority < 0,0001).

Pierwszorzędowy złożony punkt końcowy dotyczący stentowanego naczynia (TVF, target vessel failure) po 1 roku wystąpił w 5\% przypadków we wszystkich trzech grupach badania. Zakrzepica w stencie wystąpiła u 4 (0,3\%) z 1172 pacjentów ze stentem uwalniającym ewerolimus, u $4(0,3 \%)$ z 1169 pacjentów ze stentem uwalniającym sirolimus i u $3(0,3 \%)$ spośród 1173 pacjentów ze stentem uwalniającym zotarolimus $(p=0,7)$. Interesujące z praktycznego punktu widzenia mogą być dane dotyczące samej procedury implantacji stentów - nie zanotowano różnic istotnych statystycznie w zakresie odsetka stentów implantowanych bezpośrednio, bez predylatacji (17\%), jak również odsetka postdylatacji (81\%). Podwójną terapię przeciwpłytkową otrzymywało 97\% pacjentów przy wypisaniu oraz $86 \%$ na koniec trwającej rok obserwacji, bez różnic między poszczególnymi inhibitorami $P 2 Y_{12}$ w badanych grupach. W dyskusji autorzy podkreślają, że badanie BIO-RESORT jest pierwszym badaniem służącym porównaniu efektów leczenia z zastosowaniem nowej generacji stentów zbudowanych z bardzo cienkich przęseł pokrytych biodegradowalnym polimerem w porównaniu z klasycznym stentem z trwałym polimerem. Wyniki trwającej rok obserwacji były bardzo dobre i porównywalne we wszystkich badanych grupach.

\section{Piśmiennictwo}

1. Serruys PW, Chevalier B, Sotomi $Y$, et al. Comparison of an everolimus-eluting bioresorbable scaffold with an everolimus-eluting metallic stent for the treatment of coronary artery stenosis (ABSORB II): a 3 year, randomised, controlled, single-blind, multicentre clinical trial. Lancet. 2016; 388(10059): 2479-2491, doi: 10.1016/S01406736(16)32050-5, indexed in Pubmed: 27806897.

2. Worthley SG, Abizaid A, Kirtane AJ, et al. RevElution Investigators. First-in-Human Evaluation of a Novel Polymer-Free Drug-Filled Stent: Angiographic, IVUS, OCT, and Clinical Outcomes From the RevElution Study. JACC Cardiovasc Interv. 2017; 10(2): 147-156, doi: 10.1016/j. jcin.2016.10.020, indexed in Pubmed: 28104208.

3. Birgelen $\mathrm{Cv}$, Kok M, Heijden Lv, et al. Very thin strut biodegradable polymer everolimus-eluting and sirolimus-eluting stents versus durable polymer zotarolimus-eluting stents in allcomers with coronary artery disease (BIO-RESORT): a three-arm, randomised, non-inferiority trial. Lancet. 2016; 388(10060): 2607-2617, doi: 10.1016/s01406736(16)31920-1. 